\title{
IDENTIFIKASI MOLEKULER ISOLAT BAKTERI SELULOLITIK DARI MANGROVE SUNGAILIAT DAN TUKAK SADAI DI PULAU BANGKA
}

\author{
Ardiansyah Kurniawan ${ }^{1}$, Suci Puspita Sari ${ }^{1}$, Euis Asriani ${ }^{1}$, Andi \\ Kurniawan ${ }^{2}$, Abu Bakar Sambah ${ }^{2}$, Asep Awaludin Prihanto ${ }^{2}$ \\ ${ }^{1}$ Fakultas Pertanian, Perikanan dan Biologi, Universitas Bangka Belitung \\ ${ }^{2}$ Fakultas Perikanan dan IImu Kelautan, Universitas Brawijaya \\ E-mail : ardian_turen@yahoo.co.id
}

Received August 2018, Accepted September 2018

\begin{abstract}
ABSTRAK
Bakteri selulolitik memiliki kemampuan degradasi selulosa dan membuat karbohidrat lebih mudah dicerna bagi ternak. Penelitian ini bertujuan untuk mengidentifikasi bakteri selulolitik di tanah, kayu lapuk dan daun dari mangrove pulau Bangka melalui skrining dan analisis gen 16s rRNA. Penelitian dilakukan dari September 2017 hingga Maret 2018. Isolat TSL7 dan TSS4 dari Mangrove Tukak Sadai dan SLS5 dari Mangrove Sungailiat yang memiliki kemampuan mendegradasi selulosa terbesar berdasarkan hasil skrining menjadi isolat yang diidentifikasi pada gen 16S rRNA untuk diurutkan dan analisis BLAST. Analisis gen bank menunjukkan kedekatan dengan Pseudomonas aeruginosa dengan query cover $37 \%-87 \%$. Hasil query cover rendah dihasilkan karena sekuens yang sesuai pendek. Kontaminasi dan perubahan komunitas karena seleksi lingkungan dengan adanya logam berat dapat menjadi penyebab dominasi Pseudomonas aeruginosa. Pseudomonas aeruginosa yang bersifat patogen tidak disarankan untuk diaplikasikan sebagai pendegradasi selulosa pakan ternak.
\end{abstract}

Kata kunci : Bakteri Selulolitik, Pulau Bangka, 16S rRNA, Mangrove

\begin{abstract}
Cellulolytic bacteria have the capability of cellulose degradation and make carbohydrates easier to digest for livestock. This study aims to identify cellulolytic bacteria in the soil, weathered wood and leaves of the Bangka mangrove island through screening and analysis of 16s rRNA genes. The study was done from September 2017 to March 2018. Isolates of TSL7 and TSS4 from Tukak Sadai Mangroves and SLS5 from Sungailiat Mangroves which had the largest ability to cellulose degrading based on the results of screening, and they identified in 16S rRNA gene for BLAST analysis and analysis. Analysis of bank genes showed proximity to Pseudomonas aeruginosa with cover queries of $37 \%-87 \%$. The results of
\end{abstract}


a low query cover are generated because the corresponding sequences are short. Contamination and changes in the community due to environmental selection in the presence of heavy metals can be the cause of the dominance of Pseudomonas aeruginosa. Pathogenic of pseudomonas aeruginosa is not recommended to be applied as a degradator for animal feed cellulose.

Keywords : Cellulolytic Bacteria, Bangka Island, 16S rRNA, Mangrove

\section{PENDAHULUAN}

Mangrove adalah ekosistem unik yang bermanfaat bagi ekosistem seperti perlindungan bahaya tsunami, habitat organisme muara dan penyuplay oksigen. Mangrove adalah ekosistem dengan kepentingan ekologis yang besar di daerah pesisir, di mana mereka menyediakan sumber makanan dan tempat hidup benih bagi banyak hewan laut dan spesies laut yang disesuaikan dengan lingkungan payau / garam (Rigonato et al., 2017). Mikroba pada mangrove memainkan peran penting dalam siklus siklus karbon organik. Bakteri selulolitik mampu merendahkan selulosa organik dan menghasilkan turunan gula sederhana dalam sedimen (Chantarasiri, 2015).

Bakteri selulolitik merupakan salah satu jenis bakteri yang terdapat pada mangrove. Bakteri selulolitik memiliki manfaat untuk mendegradasi selulosa sehingga dapat dimanfaatkan untuk peningkatan penyerapan nutrisi bahan alam berserat. Bakteri selulolitik ditemukan di hutan mangrove di Bantul (Nurrochman, 2015), Tanah Muara Sungai Gunung Anyar, Surabaya (Maulani, 2014), sedimen dari rawa bakau di Sungai Rayong, Provinsi Rayong, Thailand (Chantarasiri, 2015) dan serasah daun mangrove di Sungailiat dan Tukak Sadai, Pulau Bangka (Kurniawan et al., 2018a).

Pulau Bangka memiliki potensi mangrove seluas 48,090 hektar yang bertebaran pada beberapa lokasi baik di Belinyu, Kabupaten Bangka, Muntok, Kabupaten Bangka Barat maupun Kurau, Bangka Tengah dan Toboli, Bangka Selatan. Kabupaten Bangka dan kabupaten Bangka Barat memiliki luas mangrove tertinggi dengan 15.136 hektar dan 18.235 hektar, dan kota Pangkalpinang memiliki luas mangrove terkecil dengan 470 hektar. Meskipun hutan mangrove di pulau Bangka mengalami penurunan akibat penambangan timah baik di darat maupun dilautan, sumberdaya dalam hutan mangrove masih memberikan dampak positif bagi kehidupan.

Pengetahuan tentang bakteri selulolitik dari mangrove di Pulau Bangka masih terbatas. Kondisi perairan dan substrat mangrove yang berubah akibat aktivitas penambangan timah memungkinkan adaptasi bakteri yang hidup di dalamnya. Resistensi bakteri dalam kondisi kontaminasi memungkinkan adaptasi dan pemilihan bakteri sehingga bakteri diidentifikasi berbeda dengan mangrove di daerah lain. Kurniawan et al. (2018b) memaparkan bahwa bakteri yang diprediksi memiliki 
kemampuan mendegradasi selulase yang berasal dari sedimen mangrove di Pulau Bangka adalah Bacillus pumilus, Pseudomonas sp., Bacillus amyloliquefacien, Bacillus alvei and Bacillus coagulant menggunakan the microbact analysis. Identifikasi bakteri masih sebatas pada analisa biokimia. Untuk itu diperlukan analisa molekuler untuk mengetahui spesies dan kekerabatannya pada bakteri dengan daya degradasi selulolase tertinggi dari hutan mangrove di pulau Bangka.

\section{MATERI DAN METODE}

Penelitian terlaksana pada bulan September 2017 - Maret 2018 dengan isolat bakteri selulolitik dari Mangrove Sungailiat, Bangka dan Mangrove Tukak Sadai Bangka Selatan. Pengujian dilakukan di Laboratorium Genetika Universitas Islam Negeri, Malang dan Laboratorium Mikrobiologi Fakultas Perikanan dan IImu Kelautan Universitas Brawijaya, Malang.

Isolat bakteri dengan kemampuan degradasi selulosa terbesar di kultur pada media nutrient broth dan diinkubasi selama 3 hari untuk selanjutnya diidentifikasi dengan metode $16 \mathrm{~S}$ rRNA. Isolasi DNA dilakukan dengan menggunakan prosedur Kit Isolasi DNA (Wizard of Genomic DNA Purification Kit dari Promega). Kemurnian terukur dan konsentrasi DNA yang diisolasi menggunakan spektrofotometer UV Biorad. Primer dirancang menggunakan perangkat lunak Oligo Analyzer versi 1.0.2., Oligo Explorer 1.1.0. dan BLAST (Basic Local Alignment Search Tool) yang bisa diakses online di NCBI. Amplifikasi gen genotip dilakukan dengan teknik Polymerase Chain Reaction atau PCR menggunakan mesin thermalcycler. Komposisi PCR dengan total volume $20 \mu \mathrm{l} /$ tube terdiri dari $6 \mu \mathrm{lddH} 2 \mathrm{O}$, kit PCM $10 \mu \mathrm{l} \mathrm{GoTaq}{ }^{\circledR}$ Green Master Mix (buffer $10 \times$ taq polymerase, dNTP, MgCl2, primer, Taq DNA polymerase, ddH2O), $1 \mu \mathrm{l}$ forward primer, sampel DNA terisolasi $1 \mu \mathrm{l}$ dan $2 \mu$ primer. Band yang paling kuat disekuensing menggunakan ABI PRISM® 310 Genetic Analyzer melalui Genetika Science. Penggabungan hasil sequencing forward dan reverse menggunakan software Bioedit. Pencarian database dilakukan melalui NCBI dengan BLAST. Konstruksi filogeni disusun menggunakan aplikasi pada web phylogen.fr.

\section{HASIL DAN PEMBAHASAN}

Isolat bakteri selulolitik dari pulau Bangka yang disekuensing untuk memperoleh kekerabatannya adalah isolat dengan daya degradasi terbesar terhadap selulase yaitu isolat dengan kode TSL 7 dan TSS 4 dari mangrove Tukak Sadai, Bangka Selatan dan SLS 5 dari sampel serasah daun mangrove di Sungailiat, Bangka. Kurniawan et al. (2018c) menyatakan bahwa isolat pendegradasi selulase menunjukkan muncuknya zona bening yang lebih besar sebagai tanda bahwa bakteri tersebut memiliki kemampuan mensekresikan enzim selulase lebih tinggi dibandingkan isolat yang lain. 
Isolat dengan sumber dan lokasi yang berbeda pada hasil isolasi DNA menunjukkan kemiripan band terkuat terdapat pada 4000 bp sebagaimana terdapat pada Gambar 1.

4000 bp

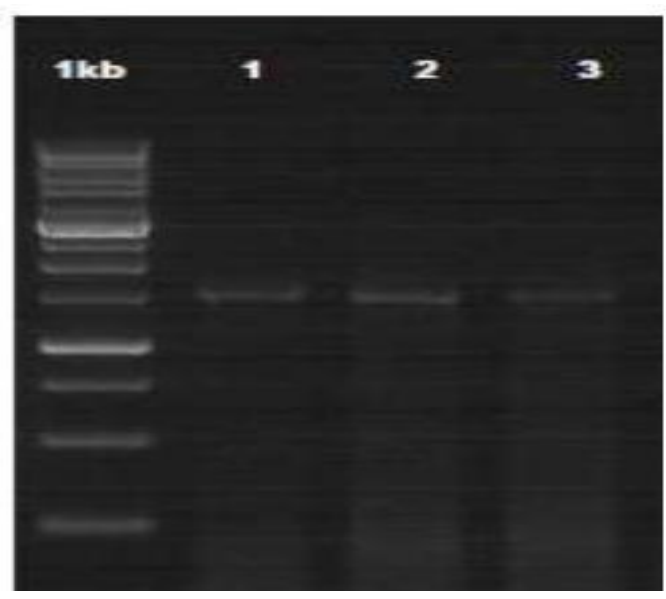

Gambar 1. Hasil isolasi DNA pada gel agarosa $0,8 \%$.

Hasil analisa BLAST dari sekuens yang diperoleh pada gen bank menunjukkan isolat TSL 7 memiliki kedekatan dengan Pseudomonas aeruginosa strain $\mathrm{ZH}$, sementara isolat TSS 4 memiliki kekerabatan terdekat dengan Pseudomonas aeruginosa strain B4 dan isolat SLS 5 memiliki kekerabatan dengan Pseudomonas aeruginosa strain F2. Hasil BLAST lebih lengkap terdapat pada Tabel $1-3$.

Tabel 1. Hasil identifikasi similaritas pada analisa sekuens isolat TSL7

\begin{tabular}{|c|c|c|c|c|c|c|}
\hline Deskripsi & $\begin{array}{c}\text { Max } \\
\text { Score }\end{array}$ & $\begin{array}{l}\text { Total } \\
\text { Score }\end{array}$ & $\begin{array}{l}\text { Query } \\
\text { Cover }\end{array}$ & E Value & Ident & Accesion \\
\hline $\begin{array}{l}\text { Pseudomonas } \\
\text { aeruginosa } \\
\text { strain ZH1 } \\
\text { 16S ribosomal } \\
\text { RNA gene, } \\
\text { partial } \\
\text { sequence }\end{array}$ & 1604 & 1604 & $74 \%$ & 0.0 & $91 \%$ & KM096830.1 \\
\hline $\begin{array}{l}\text { Bacterium } \\
\text { AW5 16S } \\
\text { ribosomal } \\
\text { RNA gene, } \\
\text { partial } \\
\text { sequence }\end{array}$ & 1602 & 1808 & $87 \%$ & 0.0 & $91 \%$ & KF964356.1 \\
\hline $\begin{array}{l}\text { Pseudomonas } \\
\text { sp. R-25016 } \\
\text { 16S rRNA } \\
\text { gene, strain }\end{array}$ & 1602 & 1815 & $87 \%$ & 0.0 & $91 \%$ & AM084027.1 \\
\hline
\end{tabular}




\begin{tabular}{lllllll}
\hline R-25016 & & & & & \\
Pseudomonas & 1600 & 1804 & $87 \%$ & 0.0 & $91 \%$ & KX859177.1 \\
aeruginosa & & & & & & \\
strain SBA & & & & & & \\
$16 S$ ribosomal & & & & & & \\
RNA gene, & & & & & \\
partial \\
sequence
\end{tabular}

Tabel 2. Hasil Identifikasi Similaritas sekuens isolat TSS4 melalui NCBI

\begin{tabular}{|c|c|c|c|c|c|c|}
\hline Deskripsi & $\begin{array}{l}\text { Max } \\
\text { Score }\end{array}$ & $\begin{array}{l}\text { Total } \\
\text { Score }\end{array}$ & $\begin{array}{l}\text { Query } \\
\text { Cover }\end{array}$ & E Value & Ident & Accesion \\
\hline $\begin{array}{l}\text { Pseudomonas } \\
\text { aeruginosa } \\
\text { strain B4 16S } \\
\text { ribosomal } \\
\text { RNA gene, } \\
\text { partial } \\
\text { sequence }\end{array}$ & 651 & 651 & $37 \%$ & 0.0 & $94 \%$ & KY457231.1 \\
\hline $\begin{array}{l}\text { Pseudomonas } \\
\text { aeruginosa }\end{array}$ & 651 & 651 & $37 \%$ & 0.0 & $94 \%$ & HM439969.1 \\
\hline $\begin{array}{l}\text { strain NBAll } \\
\text { AFP-9 16S } \\
\text { ribosomal } \\
\text { RNA gene, } \\
\text { partial } \\
\text { sequence }\end{array}$ & & & & & & \\
\hline $\begin{array}{l}\text { Pseudomonas } \\
\text { aeruginosa } \\
\text { strain } 84, \\
\text { complete } \\
\text { genome }\end{array}$ & 649 & 2589 & $37 \%$ & 0.0 & $94 \%$ & CP021999.1 \\
\hline $\begin{array}{l}\text { Pseudomonas } \\
\text { aeruginosa } \\
\text { strain D-16 } \\
16 S \text { ribosomal } \\
\text { RNA gene, } \\
\text { partial } \\
\text { sequence }\end{array}$ & 649 & 649 & $37 \%$ & 0.0 & $94 \%$ & KY885170.1 \\
\hline
\end{tabular}


Tabel 3. Hasil Identifikasi Similaritas sekuens isolat SLS 5

\begin{tabular}{|c|c|c|c|c|c|c|}
\hline Deskripsi & $\begin{array}{l}\text { Max } \\
\text { Score }\end{array}$ & $\begin{array}{l}\text { Total } \\
\text { Score }\end{array}$ & $\begin{array}{l}\text { Query } \\
\text { Cover }\end{array}$ & E Value & Ident & Accesion \\
\hline $\begin{array}{l}\text { Pseudomonas } \\
\text { aeruginosa } \\
\text { strain F2-8 } \\
\text { 16S ribosomal } \\
\text { RNA gene, } \\
\text { partial } \\
\text { sequence }\end{array}$ & 874 & 874 & $79 \%$ & 0.0 & $84 \%$ & KT735220.1 \\
\hline $\begin{array}{l}\text { Pseudomonas } \\
\text { aeruginosa } \\
\text { strain Al-Khrj1 } \\
\text { 16S ribosomal } \\
\text { RNA gene, } \\
\text { partial } \\
\text { sequence }\end{array}$ & 872 & 872 & $79 \%$ & 0.0 & $84 \%$ & KY123854.1 \\
\hline $\begin{array}{l}\text { Pseudomonas } \\
\text { aeruginosa } \\
\text { strain Y5W } \\
\text { 16S ribosomal } \\
\text { RNA gene, } \\
\text { partial } \\
\text { sequence }\end{array}$ & 869 & 869 & $79 \%$ & 0.0 & $84 \%$ & $\begin{array}{c}\text { MF370906. } \\
1\end{array}$ \\
\hline $\begin{array}{l}\text { Pseudomonas } \\
\text { aeruginosa } \\
\text { strain } \\
\text { DM_S25H } \\
\text { 16S ribosomal } \\
\text { RNA gene, } \\
\text { partial } \\
\text { sequence }\end{array}$ & 869 & 869 & $79 \%$ & 0.0 & $84 \%$ & $\begin{array}{c}\text { MF599535. } \\
1\end{array}$ \\
\hline
\end{tabular}

Nilai query cover yang rendah yaitu berkisar antara $37-87 \%$ memberikan kemungkinan bahwa sekuens DNA hasil isolasi memiliki panjang rantai DNA yang lebih pendek sehingga hanya sebagian kodon yang dapat dibandingkan. Query cover isolat TSL7 mencapai $79-87 \%$ dengan kesesuaian identifikasi mencapai $91 \%$, sementara isolat TSS4 memiliki query cover hanya 37\% meskipun kededuaiannya $94 \%$ yang dapat diartikan $63 \%$ rantai sekuens DNA Pseudomonas aeruginosa tidak terbandingkan dalam analisa ini. Hasil rekonstruksi filogenetik isolat TSL 7, TSS 4 dan SLS 5 terdapat pada Gambar 2 - 4. 


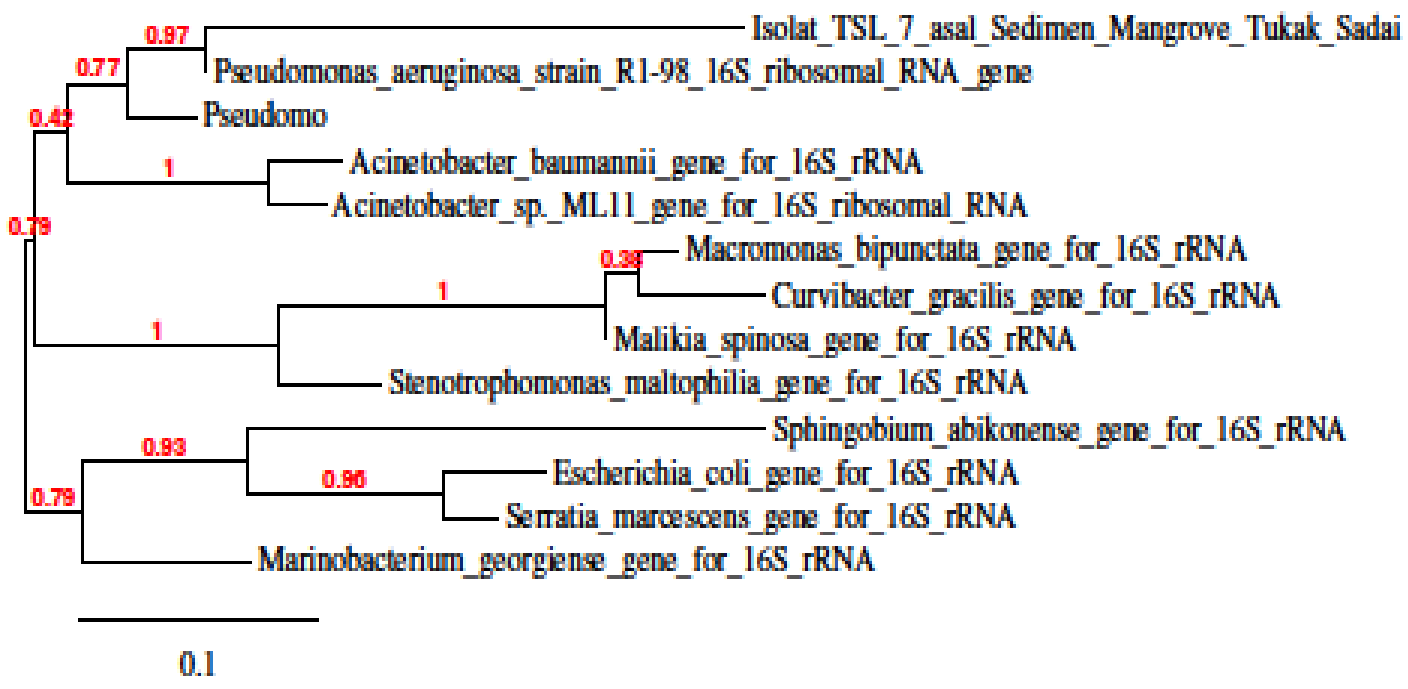

Gambar 2 . Pohon Filogenetik isolat bakteri TSL7 dari sedimen mangrove Tukak Sadai

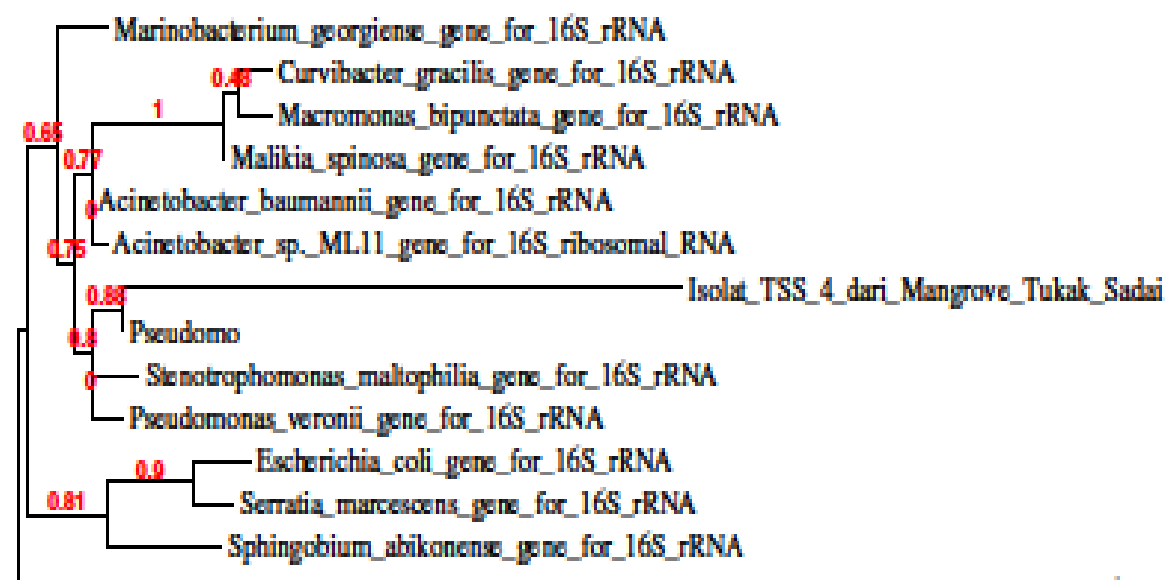

0.2

Gambar 3 . Pohon Filogenetik TSS4 bacteria isolates dari serasah daun Mangrove Tukak Sadai 


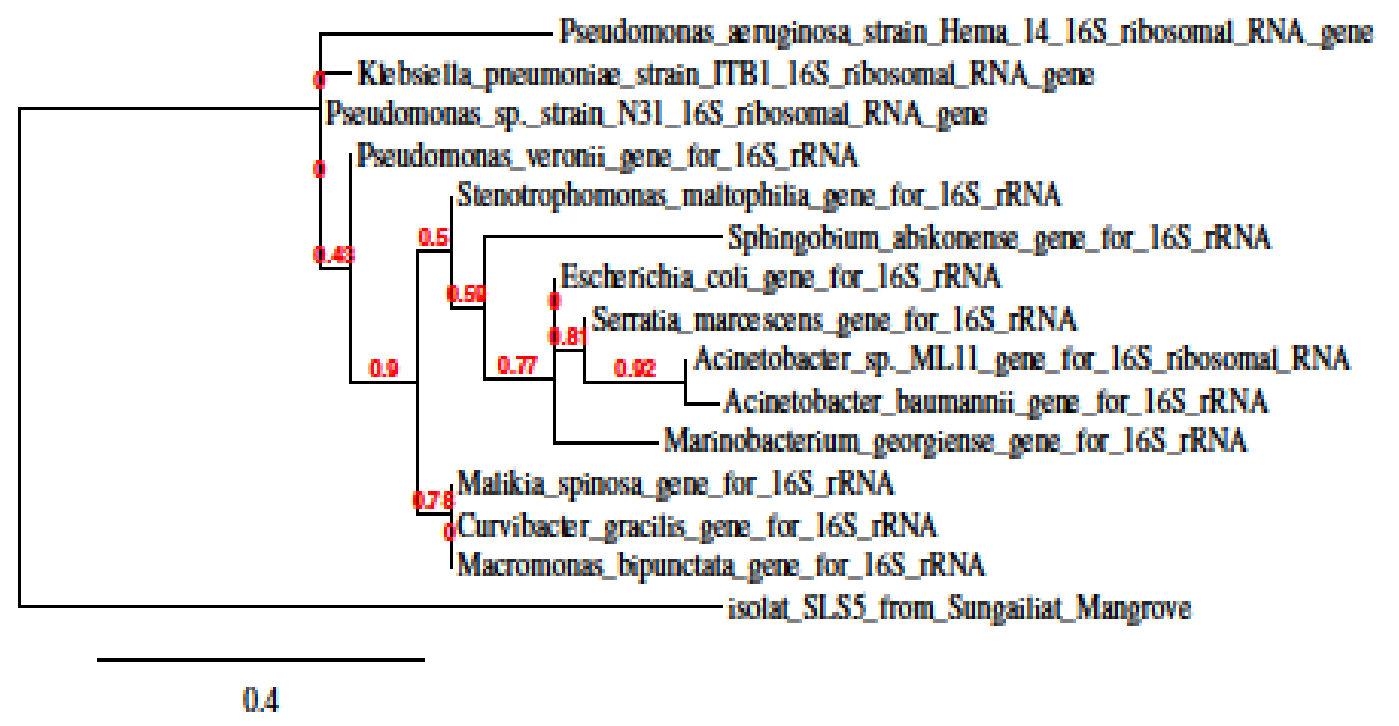

Gambar 4 . Pohon Filogenetik isolat SLS5 bacteria isolates dari Mangrove Sungailiat

Hasil sekuens dan konstruksi filogenetik pada ketiga isolat dengan daya degradasi selulase terbesar mengarah pada spesies yang sama yaitu Pseudomonas aeruginosa. Strohl (2001) menyatakan bahwa Pseudomonas aeruginosa merupakan bakteri gram negatif aerob obligat, berkapsul, mempunyai flagella polar sehingga bakteri ini bersifat motil, berukuran sekitar 0,5-1,0 $\mu \mathrm{m}$ dan secara luas dapat ditemukan di alam, contohnya di tanah, air, tanaman, dan hewan. Mayasari (2005) menambahkan bahwa Pseudomonas aeruginosa menjadi penyebab ada beberapa infeksi diantaranya pada luka dan luka bakar. Kondisi ini menurunkan kemungkinan aplikasi isolat TSL7, TSS4 dan SLS5 menjadi bakteri selulolitik yang diaplikasikan pada degradasi selulosa bahan pakan ikan. Lubis et al. (2013) menunjukkan bahwa Pseudomonas aeruginosa merupakan bakteri patogen dan teridentifikasi pada luka ikan patin yang menunjukkan gejala klinis pergerakan lemah dan cenderung dipermukaan air dan perubahan warna kulit. Belum diketahui efek Pseudomonas aeruginosa pada saluran pencernaan ikan meskipun $P$. aeruginosa memiliki kemampuan menghambat bakteri patogen penyabab penyakit ikan lainnya yaitu Aeromonas hydrophila (Putri et al., 2008).

Munculnya Pseudomonas aeruginosa sebagai bakteri selulolitik dominan pada sampel lumpur, kayu lapuk dan serasah daun dari mangrove di Pulau Bangka dapat dimungkinkan karena adanya kontaminasi sebagaimana pendapat Deepika et al. (2015) bahwa strain Pseudomonas aeruginosa KVD-HM52 diisolasi dari endapan mangrove yang terkontaminasi minyak menunjukkan aktivitas antijamur yang signifikan. Ritonga (2012) juga menunjukkan bahwa bakteri Pseudomonas menjadi salah satu bakteri yang diisolasi dari serasah daun $R$. apiculata yang mengalami proses dekomposisi selain Bacillus, 
Flavobacterium, Alcaligenes, Sporosarcina, Staphylococcus, Micrococcus, Kurthia, Escherichia coli, Planococcus, Mycobacterium.

Hasil identifikasi yang menunjukkan spesies yang sama meskipun sampel diambil dari sumber dan lokasi yang berbeda memunculkan kemungkinan terjadinya seleksi dengan faktor-faktor yang berpengaruh pada lingkungan. Perubahan komunitas bakteri dengan adanya seleksi oleh keberadaan logam berat dapat menghambat pertumbuhan bakteri lain. Feng Yao (2017) menjelaskan komposisi komunitas bakteri sangat kuat dipengaruhi oleh variabel logam berat yang ada pada sedimen yang ditemukan di Teluk Jiaozhou. Di bawah tekanan polusi logam berat, terjadi pergeseran struktur komunitas bakteri sangat signifikan antara sampel yang tercemar dan sampel sedimen. Organisme yang sudah toleran menjadi lebih kompetitif dan dengan demikian lebih banyak. Sementara Pulau Bangka yang identik dengan pertambangan timah terindikasi mengalami peningkatan kandungan logam berat pada sedimen maupun perairannya diantaranya : kandungan logam berat $\mathrm{Pb}$ (timbal) yang melebihi batas aman di muara Sungai Batu Belubang, Bangka Tengah (Wahyuni, 2013), terjadinya kontaminasi logam $\mathrm{Pb}$ dalam sedimen di perairan Bangka Selatan lebih banyak dibandingkan dengan Bangka Utara dan Bangka Timur (Ahmad, 2013) dan kandungan logam berat $\mathrm{Cd}$ dan $\mathrm{Pb}$ di sedimen lebih tinggi bila dibandingkan dengan kandungannya di air laut pada pesisir di Bangka Selatan (Sari et al., 2017). Munculnya tambang timah inkonvensional diduga memberikan kontribusi pada peningkatan kandungan logam berat. Sari dan Rosalina (2014) menyatakan bahwa pada areal mangrove seringkali masih terdapat aktivitas perahu nelayan dan tambang inkonvensional ( $\mathrm{TI}$ ) apung. Pertambangan timah disekitar mangrove memiliki resiko pada pencemaran sebagaimana pernyataan Pramudji (2000) bahwa penambangan di daerah hutan mangrove memiliki resiko hutan mangrove akan tercemar, karena limbah dan proses untuk memperoleh hasil penambangan, misalnya pencucian, pemisahan kimiawi dan penapisan tersebut kemudian dibuang di daerah hutan mangrove.

\section{KESIMPULAN}

Isolat TSL7, TSS4 dari Mangrove Tukak Sadai dan SLS5 dari Mangrove Sungailiat yang menghasilkan degradasi selulosa terbesar memiliki kekerabatan dengan Pseudomonas aeruginosa pada analisis sekuens 16S rRNA dengan query cover 37\% - 87\%. Query cover yang rendah disebabkan rantai sekuens yang pendek. Kontaminasi dan perubahan komunitas akibat seleksi lingkungan dengan keberadaan logam berat dimungkinkan menjadi penyebab dominasi Pseudomonas aeruginosa. Pseudomonas aeruginosa yang bersifat patogen tidak disarankan untuk diaplikasikan sebagai pendegradasi selulosa pakan ternak. 


\section{UCAPAN TERIMA KASIH}

Penulis menyampaikan terima kasih kepada Ditjen Penguatan Riset dan Pengembangan Kementerian Riset, Teknologi, dan Pendidikan Tinggi atas pendanaan penelitian kerjasama perguruan tinggi tahun 2017-2018 antara universitas Bangka Belitung dan Universitas Brawijaya.

\section{DAFTAR PUSTAKA}

Ahmad Fasmi, 2013. Distribusi Dan Prediksi Tingkat Pencemaran Logam Berat (Pb, Cd, Cu, Zn, Dan Ni) Dalam Sedimen Di Perairan Pulau Bangka Menggunakan Indeks Beban Pencemaran Dan Indeks Geoakumulasi. Jurnal IImu dan Teknologi Kelautan Tropis, Vol. 5, No. 1.

Chantarasiri A. 2015. Aquatic Bacillus cereus JD0404 isolated from the muddy sediments of mangrove swamps in Thailand and characterization of its cellulolytic activity. Egypt J Aquat Res. 41(3).

Deepika K.V., P.Ramu Sridharb, P.V Bramhacharia. 2015. Characterization and antifungal properties of rhamnolipids produced by mangrove sediment bacterium Pseudomonas aeruginosa strain KVD-HM52. Biocatalysis and Agricultural Biotechnology. Vol 4 No. 4.

Kurniawan et al, 2018b. Isolation and Identification of cellulolytic bacteria from mangrove sediment in Bangka Island. IOP Conf. Series: Earth and Environmental Science 137.

Kurniawan et al, 2018c. Isolasi Dan Identifikasi Bakteri Pendegradasi Selulosa Asal Ekosistem Mangrove Tukak Sadai, Bangka Selatan. Jurnal Perikanan Pantura. Volume 1, Nomor 2

Kurniawan, A., Prihanto, A.A., Puspita, S., Kurniawan, A., Asriani, E., Sambah, A.B. 2018a. Cellulolytic Bacteria Mangrove Leaf Litter In Bangka Island. Samakia: Jurnal Ilmu Perikanan, 9 (1) : 06-11

Lubis Y.P, Yunasfi, R. Leidonald, 2013. Jenis-Jenis Bakteri Pada Luka Ikan Patin (Pangasius djambal). Aquacoastmarine. Universitas Sumatera Utara, Medan.

Maulani SH. 2014. Isolation And Identification Of Cellulolitic Bacteria From Land Of Estuary River Mangrove Gunung Anyar, Surabaya. ADLN Perpustakaan Universitas Airlangga.

Nurrochman F. 2015. Exploration of Cellulolytic Bacteria From Land Mangrove Forest Baros Kretek, Bantul, Yogyakarta. Publication 
manuscript. Faculty of Teacher Training and Education. Muhammadiyah Surakarta University.

Putri. R.W, W. Tjahjaningsih, D. Handijatno. 2008. Daya Antibakterial Pigmen Pyocyanin Dari Isolat Pseudomonas aeruginosa Terhadap Aeromonas hydrophila Secara In Vitro. Berkala Ilmiah Perikanan Vol. 3 No. 1.

Rigonato J, Kent AD, Gumiere T, Branco LHZ, Andreote FD, Fiore MF. 2017. Temporal assessment of microbial communities in soils of two contrasting mangroves. Brazilian J Microbiol

Strohl WA, Rouse H, Fisher BD. 2001. Microbiology. USA: Lippincott Williams \& Wilikns.

Sari P.S, D. Rosalina, W. Adi, 2017. Bioakumulasi timbal (Pb) dan cadmium $(\mathrm{Cd})$ pada lamun Cymodocea serrulata di Perairan Bangka Selatan. Depik Jurnal IImu-IImu Perairan, Pesisir dan Perikanan. Volume 6, Number 2.

Sari P.S. dan D. Rosalina, 2014. Tingkat Keberhasilan Penanaman Mangrove pada Lahan Pasca Penambangan Timah di Kabupaten Bangka Selatan. Maspari Journal, Vol. 6, No. 2.

Wahyuni. H, S.B Sasongko, D. P. Sasongko, 2013. Kandungan Logam Berat pada Air, Sedimen dan Plankton di Daerah Penambangan Masyarakat Desa Batu Belubang Kabupaten Bangka Tengah. Prosiding Seminar Nasional Pengelolaan Sumberdaya Alam dan Lingkungan. 